This is an Accepted Manuscript of an article published by Taylor \& Francis in Journal of Post-Keynesian Economics on 15 January 2016, available online:

http://www.tandfonline.com/10.1080/13563467.2016.1115826 . 


\section{Neoliberal growth models, monetary union and the Euro Crisis. A post-Keynesian perspective}

Engelbert Stockhammer, Kingston University

Version 3.01 Oct 2015

The paper has been accepted for publication in New Political Economy (Oct 2015).

Abstract. The paper offers an account of the Euro crisis based on post-Keynesian monetary theory and its typology of demand regimes. Neoliberalism has transformed social and financial relations in Europe but it has not given rise to a sustained profit-led growth process. Instead, growth has relied either on financial bubbles and rising household debt ('debt-driven growth') or on net exports ('export-driven growth’). In Europe the financial crisis has been amplified by an economic policy architecture (the Stability and Growth Pact) that aimed at restricting the role of fiscal policy and monetary policy. This neoliberal economic policy regime in conjunction with the separation of monetary and fiscal spheres has turned the financial crisis of 2007 into a sovereign debt crisis in southern Europe.

Keywords: Euro crisis, neoliberalism, European economic policy, European integration, financial crisis, sovereign debt crisis

Acknowledgements. The paper was presented at the SPERI conference 2013, Sheffield, and EISA conference 2013, Warsaw. The author is grateful for discussions there and to Cedric Durand, Gilles Christoph, Karsten Köhler, Paul Auerbach, Alvaro Santos and anonymous referees for helpful comments. The usual disclaimers apply. 


\section{Neoliberal growth models, monetary union and the Euro Crisis. A post-Keynesian perspective}

\section{Introduction}

The financial crisis began in the market for derivatives of US subprime mortgages and translated into the worst recession since the 1930s in all advanced economies. However, seven years after the crisis began the experience differs dramatically across countries. Only in parts of Europe has the crisis mutated into a sovereign debt crisis and economic depression. This paper offers an analysis that puts neoliberalism at the very heart of the crisis in Europe both as a cause of the imbalances at the root of the crisis and, specific to the EMU (Economic and Monetary Union), as an economic policy regime that has turned the financial crisis into a sovereign debt crisis.

Neoliberalism is an attempt to modernise liberal thought and policy after the great wars. Theoretically it has modified the conceptualisation of markets, states and individuals (Foucault 2008, Mirowsky and Plehwe 2009). Politically it encompasses a variety of projects that have been shaped by the specific historical constellations and power relations (Harvey 2005, Fourcade-Gourinchas and Babb 2002). The contribution of the paper is that it uses post-Keynesian Economics (PKE) to provide a macroeconomically-grounded analysis of variegated neoliberalism. We, firstly, use the post-Keynesian (PK) typology of demand regimes to analyse the dynamics and instability of debt-driven and export-driven growth and, secondly, PK monetary theory which argues that money has a state origin but is created by private financial institutions. 
We argue that neoliberalism has given rise to an unstable finance-dominated accumulation regime. It has not led to a sustained profit-led growth process, but to two complementary growth models that rely either on financial bubbles and rising household debt ('debt-driven growth') or on rising export surpluses ('export-driven growth'). In Europe, their emergence is closely linked to the process of European integration along neoliberal lines. It has, on the one hand, fostered financial deregulation and, as a consequence, financial flows that fuelled the housing bubbles notably in Spain and Ireland. On the other hand it has paired fixed exchange rates with a neoliberal economic policy regime that has allowed the German ruling classes to pursue a neo-mercantilist strategy. Trade imbalances as well as the build-up of debt are closely related to neoliberal strategies.

Economic and Monetary Union (EMU) came with an economic policy package that is rule bound and has proven exceptionally dysfunctional during the crisis. It is inspired by ordoliberalism, a variante of neoliberalism, which aims at aims at constraining government intervention and has an anti-Keynesian logic. This policy regime favours downward flexible wages (or 'internal devaluation') as the preferred adjustment mechanism, which creates a deflationary bias and puts the adjustment burden on the deficit countries. We argue that the imposition of rigid rules on monetary and fiscal policy and the exposure of government finances to market pressures is not an accident, but an integral part of the neoliberal project. These constraints have become binding in the crisis, preventing national fiscal policies from counteracting the recession. Worse, it has imposed pro-cyclical austerity policies on those countries most affected by the crisis. The separation of money and central banks in this framework has created a highly unstable situation that undermines nation states’ ability to act. The resulting dialectics between the private and the public sector debt helps explaining why the economic crisis turned into a sovereign debt crisis under EMU. 
In a nutshell, the PK interpretation regards the internal and external imbalances as arising from neoliberal growth models. Both financialisation and neo-mercantilist wage suppression have played a critical role here. However, only in the context of the separation of monetary and fiscal spaces of EMU did the recession lead to a sovereign debt crisis. And only with austerity policies imposed on countries in crisis did recession turn into depression.

The paper is structured as follows. Section 2 introduces PKE, which features state-backed fiat money that is created by commercial banks and offers a typology of growth models along the pattern of demand formation and changes in income distribution. Section 3 analyses the export-driven and debt-driven growth models in Europe. It substantiates the distinction empirically and clarifies differences in PK and competing explanations. Section 4 discusses Neoliberalism and the EMU's economic policy regime, which eliminates the classic tools of national economic policy. Section 5 highlights how the neoliberal European economic policy regime has amplified the crisis and discusses the dialectics of public and private debt. Section 6 concludes by outlining a Keynesian alternative for European economic policy.

\section{Post-Keynesian Economics, demand regimes and monetary theory}

In the wake of the Great Depression Keynes argued that effective demand is the key for understanding crises. Keynesian theory then bifurcated into a stream that tried to create a synthesis with neoclassical economics and a radical stream that developed Keynes' short-run theory into a growth theory and opposed its assimilation into mainstream economics (Lavoie 2009, King 2002). This latter stream is known on as post-Keynesian (PK) theory. In contrast to its mainstream cousin it emphasises fundamental uncertainty as a pervasive feature of a 
capitalist economy, rejects methodological individualism and uses a class-analytic macroeconomic framework where social conflict and power relations are key for understanding inflation and income distribution.

The concept of effective demand is the unifying theme for PKE. In a situation of involuntary unemployment the level of effective demand will determine the level of output. Effective demand in PKE is monetary demand and Walby (2013) identifies PKE (under the label 'heterodox') as one of four frameworks for the analysis of finance. First, money is a liquid asset that is held, in part, to allow flexibility in a world with an uncertain future. Money is thus, in particular in times of crises, held as an asset and not as a means for real transactions. Second, money is created endogenously as a side effect of commercial bank lending. In the PK view credit creates deposits, not vice versa as in most standard economics textbooks. Money is neither a commodity (as in Marxian and classical economics) nor is created by central banks (as in Monetarist theory). Third, while money is created, in the modern economy, by private banks, its origins lie with the state and sovereign authority. The state is not only the largest borrower, but it also uses legal and coercive powers to establish its currency. State authority is at the foundation of the hierarchy of monies. This analysis of money has great similarity with that of economic sociologists like Ingham (2004) or anthropologists like Graeber (2011). Money is based on sovereign power but is created by profit-seeking private institutions. Forth, in a monetary production economy the lending decisions of banks become a key variable. Keynes (1936) and Minsky (1986) highlight the role of financial factors, credit and leverage cycles are an important explanation of business cycles and economic crises as private lending decisions tend to be highly pro-cyclical, amplifying booms and trapping the economy in liquidity and debt-overhang crises. 
In its analysis of demand regimes PKE has highlighted the effect of changes in income distribution on effective demand. Bhaduri and Marglin (1990) formulate a Keynes-Marx synthesis model to analyse changes in the distribution between capital and labour and their demand effects. A rise in the wage share has a negative effect on investment (higher profits lead to higher investment), a positive effect on consumption (because capitalists save more than workers) and a negative effects on net exports (because the higher wages imply a loss of competitiveness). The net effect will depend on the relative size of the partial effects and may differ by country and time period. If the net effect of a rise in the wage share is positive, i.e. if the consumption effect outweighs the investment (and net export effect), the demand regime is called wage led, if it is negative it is called profit led (Lavoie and Stockhammer 2013). ${ }^{1}$

We argue that PKE can provide important insights in the nature and dynamics of neoliberalism and, in particular, the articulation of crisis of the Euro area. PKE differs from mainstream economics, the Varieties of Capitalism (VoC) approach and Marxist Political Economy (MPE) on several grounds. First, it has a strong focus on demand formation, whereas neoclassical theory, VoC and MPE all tend to favour supply-side factors. PKE offers an analysis of demand regimes that allows for wage-led as well profit-led growth. There is no a priori assumption that profits get reinvested and higher wage growth can result in higher aggregate demand. VoC routinely assumes that wage moderation has positive growth and

\footnotetext{
${ }^{1}$ A similar set of distinctions can be made with respect to debt. An increase in debt will have expansionary effects as far as debtors have a higher propensity to spend than creditors. However, it will also have a negative effect, typically delayed, as higher debt levels imply higher interest payments from debtors to creditors, which dampens aggregate demand (Dutt 2006).
} 
employment effects; in other words they assume a profit-led demand regime. ${ }^{2}$ Marxist theory usually has a secondary, short-run role for demand, but it tends to assume that growth is profit-led in the long run (e.g. Dumenil and Levy 1999, Foley and Michl 1999). Crises originate from the (lack of) production of surplus value or from a rising organic composition of capital, not from lack of demand. Indeed, in Marxist theory crises are often regarded as rooted in overaccumulation, i.e. excessive investment due to competitive pressures (e.g. Brenner 1998). MPE has theorised constellations that PK would characterise a wage-led demand regime under the heading of underconsumption crises. However, these constellations create a tension to the Marxist theory of exploitation, because they allow for increased wages to have a positive effect on profitability. The link between exploitation and profitability thus gets broken.

Second, PKE theory of money is unique in that the dialectics between the state and the private sector in the origins of money, the endogenous and pro-cyclical nature money creation, and the importance of debt for understanding crises. This contrasts to mainstream economics and MPE, which view money, as regards its origin, as a produced commodity. Neoclassical economics regards money as an efficient private-sector improvement upon the inconveniences of a barter economy. MPE regards money as a commodity, which is why it can serve as the general equivalent in exchange relations (Marx 1976, 162f; de Brunhoff and

\footnotetext{
${ }^{2}$ A similar argument can be made for mainstream economics. New Keynesian economics has a short-run role for aggregate demand, but asserts the dominance of supply-side factors in the long run and it usually is silent on the possibility of wage-led growth. Indeed, a downward-sloping labour demand function, i.e. a profit-led demand regimes, are routinely assumed.
} 
Foley 2007). ${ }^{3}$ VoC has no theory of money, but frequently uses the distinction of marketbased vs. bank-based financial systems.

PKE is a coherent, if marginalised school of thought within the economics discipline and has been able to develop an academically productive research program. However, it is also narrow in scope and is restricted to the economic domain. Social phenomena like classes or institutions do play an explanatory role in the analysis, but are taken as given. Unlike MPE PKE does not offer a theory of the state or of power relations which may explain why it has of yet received limited attention by other social scientists. In our view both PKE and social and political scientists could benefit from cooperation.

\section{Neoliberal growth models and the imbalances in Europe}

There is an extensive debate on the nature of neoliberalism, where globalisation, financialisation and rising inequality have been identified as key features (Foucault 2007, Harvey 2005, Brenner et al 2010, Duménil and Lévy 2004, Glyn 2006, Dardot and Laval 2013). Brenner et al (2009) provide an insightful typology of theoretical conceptions of neoliberalism by distinguishing between VoC, Historical Materialist International Political Economy (HM-IPE) and neo-Foucauldian approaches. VOC regards neoliberalisms as a generalisation of the liberal market economy model; HM-IPE analyses neoliberalism as a

\footnotetext{
${ }^{3}$ There are several recent attempts to update Marxian theory of money and finance (e.g. Crotty 1985, Lapavitsas 2000, Bellofiore 2005). These build on Marx’ analysis of credit cycles in volume III of Capital and usually heavily draw on PK theory and to various degrees go beyond a commodity theory of money. In so far as they do that they are, often implicitly, parting with the labour theory of value: if money is not a produced commodity, then commodity exchange is not an exchange of equivalents as claimed in Volume I of Capital (Marx 1976).
} 
global project of restoration of class power via financialisation and globalisation, which is underpinned by an emerging trans-national capitalist class; the neo-Foucauldian approach highlights the haphazard and sporadic proliferation of neoliberalising political rationalities, which take on a de-centred dynamic. Brenner et al then proceed to endorse a concept of variegated neoliberalisation that seeks to keep balance between the diversity of neoliberal experiences and coherent concept of neoliberalism. However, in doing so they operate on a high level of abstraction and offer little specific analysis of neoliberal variegation. Jessop (2011) moves further by advocating the concept of variegated capitalism highlighting the conflictive nature of capitalism, which gets only temporarily regulated by spatio-temporal institutional fixes. His analysis recognises forces that transcend nation states like financialization and globalization, but also the differentiating forces brought about by centreperiphery relations. Overall he presents an ambitious research program for societal analysis, but does not offer an analysis of the economic dynamics itself. PKE can offer a typology of growth models that clarifies variegation in terms of demand regimes and highlights the contradictory dynamics of neoliberalisation. In analysing its macroeconomic logic we do treat neoliberalism as a system rather than as a sporadic proliferation of practices.

From a macroeconomic viewpoint neoliberalism has been highly effective in restructuring in labour relations and the financial sphere. In the Anglo-Saxon countries neoliberalism came with an outright attack on organized labour (the miners' strike in Great Britain and the air traffic controllers' strike in the USA). In continental Europe the organisational strength of labour was eroded by two decades of high unemployment, welfare state retrenchment and globalization. The effects of these events on income distribution have been profound (see Atkinson et al. 2012 on top incomes and Stockhammer 2016 on wage shares). Financial deregulation has a domestic and an international dimension. Capital flows between countries 
have been liberalized, and within countries deregulation has allowed for financial innovation, eventually fuelling a rise in debt and speculative activities. Financial ratios such as stock market capitalization, derivatives turnover or cross-border lending have soared and the income shares of financial capital have increased considerably (Duménil and Lévy 2004). Moreover, the influence of financial investors on non-financial businesses has increased substantially under the so-called shareholder value revolution (Lazonick and O’Sullivan 2000). These structural changes have been summarily called financialization and plays a key role in our analysis of the structure of accumulation (Stockhammer 2012b, Hein 2012).

Neoliberalism has led to a polarisation of income distribution expressed in rising profits and top incomes, but remarkably, this has nowhere translated into a business investment boom. Capitalists did not invest their profits, which is at odds with Marx’s analysis in Capital, where they are forced to do so by competitive pressures. Keynesians have long argued that investment decisions are not reducible to optimising behaviour or competitive pressures, but retain a large degree of autonomy and are shaped by social conventions, mass psychology and the historically specific institutional forms of the firm. Table 1 provide a simple framework to classify growth regimes along two axes. First, the demand regime can be profitled or wage-led, i.e. the effect of an increase in inequality, measured by the profit share, can be positive or negative. Second, actual distributional changes can be pro-capital (higher inequality) or pro-labour (lower inequality).

Table 1 about here

This simple framework allows for a rich analysis that can be used to compare different economic theories as well as different country experiences in specific historic periods. Cell 
$(1,1)$ depicts a constellation of rising inequality in a profit-led demand regime. This would give a virtuous, profit-led growth model. In fact this constellation depicts the trickle-down economy that many neoliberals of the early 1980s were propagating. Rising inequality is a healthy thing because it comes with growth, which will eventually benefit the poor. This is 'neoliberalism in theory'. Cell $(1,2)$ has rising wages in a profit-led economy, which will not give rise to a viable growth model, but rather to stagnation. It is this scenario that Margret Thatcher was alluding to when she said 'there is no alternative': social reform is doomed because it cannot generate growth. Cell $(2,1)$ combine a wage-led demand regime with rising inequality. This combination cannot deliver a stable growth model, but creates a downward pressure on demand. However, growth can still occur if there are other stimulants of growth. Indeed, from a PK view, it is this cell were actually existing neoliberalism resides. Empirical studies (surveyed by Onaran and Galanis 2014) mostly conclude that private domestic demand is wage-led. Rather than generating a profit-led growth regime, neoliberalism has relied on financialisation and globalisation as means for demand stimulation. This has resulted in two distinct growth models, which are both unstable: debt-driven growth and export-driven growth. Both allow for growth, but are intrinsically unstable, because they require increasing debt to income ratios. In the case of the debt-driven model it requires domestic debt; in the case of the export-driven model it requires foreign debt of the trade partners. It is these rising mountains of debt that erupted in the crisis.

PKE thus offers a simple framework that highlights the following features of neoliberalism. First, there is tension between what we have called neoliberalism in theory and actually existing neoliberalism. Second, actual neoliberalism relies on external stimulation of demand, which typically comes with higher debt and is thus prone to instability. Third, there are at 
least two types of neoliberalism: a (domestic) debt-driven and an export-driven model. In other words, there is a finance-led as well as an industrial version of neoliberalism.

Let us now turn to the empirical picture for the European countries. Stockhammer et al (2011) and Onaran and Galanis (2014) provide evidence that the Euro area overall is a wageled demand regime. ${ }^{4}$ Individual European countries, in particular ones with small open economies may be profit-led, because of the net export component of aggregate demand, but as European countries mostly trade among each other, these effects to a large extent cancel out at the European level. Growth has not been the result of a profit-led growth regime. Rather, two different growth models have emerged: the Anglo-Saxon and southern European countries developed a debt-driven growth model, which was driven by increasing household debt, strong consumption demand and, in some cases, a residential investment boom (Crouch 2009 refers to this as 'privatised Keynesianism'). Other countries, namely Germany, China and Japan adopted an export-driven growth model, where domestic demand is weak and growth relies on export surpluses. Germany pursued this strategy particularly aggressively with average real wages stagnating in the decade prior to the crisis and a sharp increase in wage inequality.

The peripheral European countries also followed a debt-driven growth model (see Hein 2013 for a systematic classification). While the level of household debt has been traditionally low, the increase in household debt, which is the variable relevant for consumption expenditures, has grown rapidly. Indeed, Table 2 shows that the increase in household debt in the southern European countries was not only above the increase in the northern European countries (with

\footnotetext{
${ }^{4}$ There are some Marx-inspired authors, who report evidence for profit-led growth regimes for several countries (e.g. Kiefer and Rada 2015)
} 
the exception of the Netherlands), but it also exceeded that of the USA and the UK. Stockhammer and Wildauer (2016) provide econometric evidence for the role of debt and property prices in determining private consumption and residential investment. The rapid expansion of credit was made possible to a significant extent through European financial integration. The EC’s policy (namely the Financial Services Action Plan) aimed at creating a single financial market for Europe (Grahl 2009). In theory this means uniform interest rates across Europe and in practise it meant massive capital flows from Germany, France and the UK to the peripheral European countries. While this initially fostered manufacturing investment (as in the case of Spain and Ireland), it soon fuelled an unsustainable property boom.

Table 2 about here

At the same time the southern European countries experienced substantially higher price and wage inflation. As a consequence the south lost competitiveness. This is illustrated in Table 3 which gives the growth in unit labour costs (ULC), a standard measure of cost competitiveness, from 2000-08. The southern European countries all had a growth of more than $24 \%$, compared to a Euro area average of $16 \%$ and Germany at 3\%. Together with fast growth in many southern countries, this resulted in substantial current account deficits, which were mirrored by export surpluses in the north. The debt-driven and export-driven growth models thus were in symbiotic relation, were credit-driven growth in the south pulled in exports from the north and Nordic trade surpluses were recycled as private credit flows to southern Europe, where they financed property bubbles and rising household debt. ${ }^{5}$ In fact

\footnotetext{
${ }^{5}$ Two qualifications are in place. First, actual trade relations are more complex relations than indicated here. For example, Germany’s largest export surpluses are with Austria and with France. Austria has had export surpluses
} 
the situation differed by country, but a massive increase in private household debt (in southern European countries) is the hallmark of this growth. With the exception of Greece, public debt was declining (see also de Grauwe 2010).

Table 3 about here

Our analysis has some similarities with those put forward by VoC proponents and by Marxist Political Economy, but also substantial differences. The VoC approach (Hall 2012, Johnston et al 2014) regards differences in wage bargaining coordination and their ability to restrain wage growth as the root of the crisis as key for explaining the crisis. Northern countries with coordinated wage bargaining systems were able to maintain competitiveness; southern countries with less coordinated wage bargaining systems did experience a loss of competitiveness. Ultimately this story regards a fixed exchange rate system and excessive wage growth in the service sectors in the southern European countries as the root of the crisis. The MPE literature (e.g. Lapavitsas et al 2010, Lucarelli 2011, Bellofiori et al 2011) offers a similar story, with a different villain. In their analysis Germany used the fixed exchange rate regime to embark on wage suppression to further competitiveness. EMU is understood as a means of German hegemony and export dominance. Both VoC and MPE stress cost differentials as the cause of imbalances. However, southern European countries not only experienced a deterioration of their competitive position, but also a better growth performance than northern countries. This fact features neither in the explanation of trade

itself. France's export position was rather balanced in the first half of the 2000s and deteriorated thereafter. Both countries had surpluses with southern European countries. Second, financial flows are quite independent of trade imbalances. In particular French and British banks have had strong exposure to southern European banks, reflecting their positions as financial centres. 
imbalances, nor is their superior growth performance itself explained. There is no explicit role for financialisation in the story. In contrast, the explanation advanced in this paper treats financialisation in the south of Europe on equal footing with export orientation and wage suppression in the north. Current account imbalances are due to German wage suppression as well as to high growth in the peripheral European countries, which was due to property price bubble made possible by financial deregulation.

\section{Neoliberalism and European economic policy}

Neoliberalism develops further classical liberalism. Dardot and Laval (2013) have highlighted the importance of ordoliberalism for European integration. Ordoliberalism maintains that a system of competitive private markets is the preferable economic system, but it goes beyond classical liberalism, firstly, in emphasising the role of government in creating markets and maintaining competition and, secondly, in arguing that states have to be subjected to strict rules and exposed to competitive pressures.

The question how and why European integration took its neoliberal shape is beyond the scope of this paper. Dardot and Laval (2013) argue that the German ordoliberals have shaped the process well before neoliberalism became the dominant ideology. They argue that the German model of Rheinish capitalism should not be confused with ordoliberalism but represents a compromise between ordoliberalism, a strong labour movement and Bismarckian conservative tradition. Dyson and Featherstone (1999) in their magisterial analysis of the making of the Maastricht Treaty conclude that it represents a victory for neoliberalism (p. 
791) and that one of its main aims was to 'bind Leviathan', i.e. to restrict the scope of state activity. ${ }^{6}$ Central bank independence has always been a key ordoliberal demand (e.g. p. 277)

In continental Europe neoliberalism often came in the guise of European integration and EU policies. In particular the free trade agreements of the Single European Act, competition policy, and, later, the services directive reflect the liberal creed. The Maastricht Treaty and the Stability and Growth Pact combined an anti-inflation priority with a restriction on fiscal policy without offering adjustment mechanisms for the imbalances that it gave rise to.

The economic policy regime in the Euro area is enshrined in the Maastricht Treaty, the Stability and Growth Pact, and the Lisbon Treaty (recent changes will be discussed in Section 5). The basic structure can be summarized as follows: First, fiscal policy is essentially national policy. The EU budget, restricted to 2\% of GDP, is too small and too inflexible to serve a macroeconomic function and cannot provide a counter-cyclical stimulus in case of crisis. Second, national fiscal policies are restricted in the short term as the budget deficit must not exceed 3\% of GDP (except in severe recessions) and they must aim at a balanced budget in the medium term. Third, monetary policy is centralized at the EU level and it is effectively inflation targeting, with the independent ECB having set the inflation target close to or below 2\%. Fourth, financial markets are liberalized, internally as well as externally. Thus the EU foregoes instruments of controlling credit growth or allocating credit. Fifth, there was a no bail-out clause, stating that neither other national governments nor the ECB will support individual countries which are facing problems in financing themselves (this is the only area where we will see fundamental changes in the policy setup). Sixth, labour

\footnotetext{
${ }^{6}$ Bonefeld (2002) argues that it was a political strategy of national capitalist classes to pursue European integration as a means to curtail corporatist national states that proved resilient domestically.
} 
markets are supposed to be flexible. The European Commission (EC) and the ECB regard wage flexibility as the cure to economic imbalances. By this they mean downward wage flexibility (they have not called for higher wages in Germany). But this anti-labour bias should not hide the fact that within the economic policy regime of EMU there is an economic logic to the argument: with fiscal policy restrained, exchange rate policy abolished and monetary policy centralized, all the standard economic policy tools are paralyzed. The burden of adjustment thus has to be carried by the labour market and wage policy.

The EU policy package is a form of neoliberalism. It is characterized by a strong belief in the efficiency of the market system, a distrust of state activity and an anti-labour bias. However, it is not a pure neoliberal setting, but subject to compromises under specific historic circumstances. For example Monetarists, which are a variant of neoliberals, have long defended flexible exchange rates. But Huerta de Soto (2012), a leading neo-Austrian economist, defends the Euro on the grounds that while it may not be the optimal currency arrangement, it does constrain government intervention.

The policy package was criticized sharply by PK economists (Arestis et al 2001; Euromemo 2011; Hein and Truger 2005; Huffschmid 2005; Bibow 2007, Stockhammer 2011): first, they predicted, reliance on labour market flexibility will not generate full employment. Wage flexibility in a crisis is likely to make things worse: wage cuts will lead to shrinking consumption demand and to deflation, which may depress demand further in a debt-burdened economy as the real (inflation-adjusted) value of debt increases. Second, the EU policy system would create a deflationary bias. In the case of imbalances within the EU, with some countries running trade deficits and others running trade surpluses, the burden of adjustment would effectively fall on the country with trade deficits. This creates a deflationary bias. The 
adjustment of the surplus countries would be inflationary and growth-oriented, whereas the adjustment of the deficit countries is deflationary. They have to dampen demand (to decrease imports) and lower their prices and wages (to restore competitiveness). The exclusive reliance on wages as the adjusting variable will create a downward pressure on wages and result in prolonged unemployment without solving the EU's problems.

\section{The crisis, the EU policy regime and the nature of money}

The Global Financial Crisis began in the US subprime sector. The underlying factors of the crisis include financial deregulation, the rise in inequality and the international imbalances that had built up. Initially the crisis hit debt-driven and export-driven economies equally. However the export-driven economies were quicker to recover as they were not suffering from a debt overhang. In the USA the crisis was countered by moderate counter-cyclical fiscal policy and by aggressive unconventional monetary policy, which we will refer to as quantitative easing (QE). In the USA the crisis turned into a weak recovery. Economic policy in Europe was less anti-cyclical. While countries adopted stimulus packages in 2008/09, from 2010 fiscal policy turned to austerity and, worse, it became most restrictive in those countries that were hardest hit by the crisis. Monetary policy in the EU tried to avoid QE as long as it could, but as the Euro crisis deepened, the ECB did expand its balance sheet. Given the different growth models and differences in economic policy, the crisis led to sharply different performances across Europe: a fragile recovery in the north and a depression in the southern European countries.

While recent developments have vindicated PK criticisms, the EU’s policy package has not changed direction, but become, as of today, more rigid and doctrinaire. The Treaty for 
Stability, Coordination and Governance in the Economic and Monetary Union (TSCG) has tightened the grip on fiscal policy (Grahl 2012). Constitutional debt breaks are to be introduced in the Euro member states; there will be an automatic obligation to austerity if public debt exceeds the 60\% target (the 1/20 rule) and the European Commission will be involved in the national budget process (the European Semester). The one area where there has been a change in direction is with respect to the no bail-out clause. The EU has, belatedly, set up a collective fund for member states that have lost access to market finance (EFSF, EMF). This fund gives loans to the countries that are misleadingly referred to as 'rescue packages' and imposes conditionality that is similar in spirit (if not as far reaching) as IMF adjustment programmes. $^{7}$

The crisis has illustrated the strong interdependence of the government sector and the financial system. The crisis thus raises interesting questions about the nature of money and the state. Economic theory is divided on the theory of money. Mainstream economics and MPE regard money as emerging from private transactions. By contrast, PK theory and economic sociology stress that debt relations and in particular government debt and the ability of governments to collect taxes in their own currency are the foundation of money (Goodhart 1998; Graeber 2011 chapters 2 and 3). Ingham (2004) stresses the state origin of money, but highlights that the social mode of production of credit money is through private banks. Money thus is a contested field that has sovereign power as a constituent element, but

\footnotetext{
${ }^{7}$ The 'rescue packages' have in no case led to a decline in public debt. For example in the case of Greece public debt has increased from 113\% 2008 to 160.6\% 2012, in Ireland from 44.2\% to 116.2\% (according to the EC's 2012 spring forecast). Essentially the 'rescue packages' have been gigantic machineries to transform private debt into public debt. Credit Suisse estimates that the second Greek rescue package reduced the private sector share in the holding of Greek government debt from 62\% to 30\% (Credit Suisse Economics Research 2012).
} 
private institutions are critically involved. This hybrid nature is also reflected in central banks. Most central banks were originally founded in order to strengthen state finances and later acquired bank supervision functions. Central banks were first lender of last resort for the state and only later became lender of last resort for private banks. Most countries' central banks are public-private hybrids, often with commercial bank representation on the crucial decision-making bodies.

This balance between the state and the private sector in the creation of money has been upset by EMU, which separated fiscal and monetary spaces and insulated the European Central Bank from national governments. Central bank independence was strengthened and the ECB was forbidden to fund governments directly. That is by design it was meant to be a lender of last resort for the private sector only. Money and monetary policy was to be insulated from the political process.

The tension between the public and private nature of money surfaces in the present crisis in the close link between public and private debt. Public debt is a private asset. Most government bonds are held by private banks and pension funds. They form the most important collateral used on money markets and repo markets (Gabor 2014, Mehrling 2011). The credibility of public debt is thus essential for the functioning of private debt markets. A sovereign debt crisis also poses a mortal threat to the respective country's banks, as they usually lose access to the private financial markets. In the Euro area (in 2010-12) this has been amplified by contagion effects as the credibility of one country's sovereign debt calls into question the quality of another country’s assets. But this dialectic between private and public debt goes further. The credibility of public debt depends, in many cases, on the assessment of private financial institutions. In the case of Spain and Italy, debt levels were 
clearly sustainable at the interest levels prior to the crisis. After the financial crisis, interest spreads on southern European countries increased sharply; essentially the banks started speculating against the governments that had rescued them (Weeks 2014). There clearly will be some interest rate (and the 7\% rate that is frequently used as a benchmark seems plausible) where debt levels are unsustainable (in the sense of unserviceable).

From the autumn of 2008 central banks in the USA, the UK and the Euro area aggressively expanded their balance sheets. The orders of magnitude are substantial: central bank balance sheets tripled in size, expanding from some 6\% of GDP to more than 20\%. Central banks initially focused on buying private assets, but from spring 2009 the Fed and the BoE bought government bonds, i.e. they supported government spending. The ECB was, in the early phase of the financial crisis, much more hesitant. It started QE later, expanded its balance sheet less, and has hardly bought government bonds. At the same time (like its American and British counterparts), it has expanded the range of credit to private financial institutions (Pisani-Ferry and Wolff 2012). In short, the ECB is playing the role of lender of last resort for the financial sector, but - different from the Fed and the BoE -not for the government sector. Only in August 2012, when the Greek sovereign debt crisis threatened to engulf the other Euro member states, did the ECB commit to accepting government bonds (under the condition that those countries submitted to the conditionality of the bailout packages). For several European countries the situation is now similar to that of developing countries which have debts in a foreign currency.

The crisis is, in our view, due to the fact that Europe has built half a European state, while seriously damaging the ability of nation states to counter an economic crisis (and by implication to underwrite social compromises). This is not an accident, but a part of the 
neoliberal agenda. The incapacitation of nation states has several dimensions. The restrictions on fiscal policy directly impede governments on the expenditure side. In particular it has forced those countries most desperately in need of expansionary fiscal policies to pursue austerity. ${ }^{8}$ The loss of monetary sovereignty means that countries cannot set interest rates and, more importantly in times of sovereign debt crisis, they don't have the lender of last resort facility to support the government. The key role of the central bank for the proper functioning of a state is illustrated by the stand-off between the Greek government and Euro group in July 2015: Once the ECB froze emergency lending to Greek commercial banks the Greek government within two week agreed to measures that it had previously, and with overwhelming public support in a referendum, rejected.

The common currency turned what would otherwise have been an exchange rate crisis into a sovereign debt crisis. The separation of monetary and fiscal space fatally weakened the ability to counteract the crisis. The set of rules effectively leaves few policy variables at the states’ availability and encourages a wage policy that aims at competitive devaluation.

To restate our explanation of the crisis: At the root of the crisis is a build up of debt, fuelled by debt-driven and export-driven variants of neoliberal grown models. These growth models were enabled by the neoliberal design of Euro area economic policy framework, which encouraged financial deregulation and cross-country capital flows while eliminating the possibility of nominal exchange rate adjustments. The crisis escalated in Europe because fiscal policy and monetary policy were less anti-cyclical than in Anglo-Saxon countries. The crisis turned into a sovereign debt crisis in southern Europe, because of the separation of

\footnotetext{
${ }^{8}$ It is difficult to assess the relative impact of this historically. After the EMS crisis the deficit countries also pursued austerity policies, but the effects of the latter were alleviated by simultaneous devaluation.
} 
monetary and fiscal spaces, or in other words the treaty-consistent refusal of the ECB to back the governments of the EU member states.

How does this interpretation of the crisis differ from other explanations? The German government and the EU are guided by a fiscal irresponsibility hypothesis, which posits that the crisis is at the root one of excessive government spending in combination with inflexible labour markets. That is the neoliberal interpretation and guides present policy. For VoC and MPE the Euro crisis is most of all the result of a fixed exchange rate regime. VoC proponents (Hall 2014, Johnston et al 2013) have argued that the southern European countries have lost competitiveness because of its uncoordinated wage bargaining system. ${ }^{9}$ In other words, Germany was better in constraining wage growth. A profit-led demand regime is implicitly assumed and there is no central role for financialisation. For many Marxists the Euro system allowed Germany to pursue a neo-mercantilist strategy via wage suppression.

Financialisation has a supporting role as it allows for a recycling of German trade surpluses to finance southern Europe’s imports (Bellofiore et al 2010, Lapavitsas et al 2010). There is some truth in these arguments, but the PK perspective highlights a different set of factors. As regards the origins of the crisis, financialisation and finance-driven growth in southern Europe plays a more central role. As regards the escalation of the crisis the neoliberal macroeconomic policy regime of the Euro area play the centre role and it is the separation of monetary and fiscal space that explains the uniquely European transformation of an economic crisis into a sovereign debt crisis. And it is the refusal of the ECB to play the lender of last resort to governments that forces national governments to adopt austerity policies.

\footnotetext{
${ }^{9}$ Nölke (2014) offers a comprehensive review of Comparative Political Economy debates on the Euro crisis, which focuses on the VoC literature, but also covers, if more selectively, some of the HM-IPE and PKE literature.
} 
Within the Historical Materialist International Political Economy literature on the Euro crisis, there have been some attempts to fuse Marxist-inspired analysis of the state and class relations with an economic analysis that draws on Marxist as well as on PK arguments. Overbeek (2011), Becker and Jäger (2012) and Ryner (2015) are closest to our approach. All of them have a substantial role for financialisation, but have a limited treatment of the macroeconomic dynamics or the demand regimes involved. Overbeek stays closest to the Marxist framework in asserting an overaccumulation crisis, but notes the importance of finance-led growth, without, however, specifying how financialisation affects demand formation. He notes that the extent of financialisation is uneven across countries, but claims that 'finance-led accumulation had become the predominant growth model, not only in the traditional centre of financial globalism, the UK, but also in most of continental Europe’ (Overbeek 2011, 35). No operational definition of finance-led accumulation is provided, but it seems to refer to the use of profits rather than to demand regimes. The sovereign debt crisis is discussed as result of private bank behaviour, with little discussion of Europe's economic policy regime. Becker and Jäger (2012) offer a contradistinction between export-oriented versus financialised economies similar to ours and, indeed, draw on a similar PK literature, while maintaining a Marx-inspired regulationist framework. The sovereign debt crisis is not analysed and the eastern and southern European countries are discussed within one group, which is unsuitable for an analysis sovereign debt crises. Ryner (2015) builds most directly on PK analysis and uses a similar notion of finance-led growth, however the focus of the paper is on the development of the 'iron cage' of ordoliberal discipline that makes up the EU's economic policy regime. Ryner explains this regime as situated in the subordinate role of European economies relative to the US financial system and as a mode of adjustment to this subordinate role. His analysis is largely complementary to ours, however he does not 
discuss the sovereign debt crisis explicitly and does not theorise the differential effect that the iron cage has on northern and southern European countries.

\section{There is an alternative}

This paper tells a rather gloomy story, but it also highlights that European Neoliberalism, while so far successful politically, has resulted in a deepening of the crisis. Europe now faces several challenges: It has to stimulate demand, re-balance its trade flows and relative prices and it has to deal with high private and public debt. In principle the cost imbalances can be dealt with by inflationary adjustment (that is adjustment in the surplus countries to increase prices and output) or by deflationary adjustment in the deficit countries (Stockhammer and Sotiropoulos 2014). The latter is presently being pursued under the name of 'internal devaluation'.

A PK economic strategy would involve a very different economic policy mix, one that breaks thoroughly with Neoliberalism (e.g. Arestis et al 2001, Hein 2013). It would use deficit spending for demand stimulation and have full employment as its overall goal. Here we want to outline the structural features of the policy package rather than specific short term measures. A PK strategy aims for an inflationary adjustment strategy, which means higher demand wage growth in surplus countries (Germany). First, wage policy would not aim at wage flexibility, but at an equitable income distribution that is consistent with relative trade positions. This would involve policies to set a system of transnationally coordinated wage bargaining that takes into consideration issues of equity and trade balances. This requires a strengthening of collective bargaining structures and ought to be complemented by a European system of national minimum wages (Schulten and Watt 2007). The macroeconomic 
aim of European wage coordination ought to be higher wage growth in the trade surplus countries which would help prevent imbalances. Simply put, southern European countries need much higher wage growth in Germany - or else they have to go into deflation.

Second, the financial sector needs restructuring and shrinking. Debt restructuring will in some cases be necessary to make debt manageable, but in general the Keynesian strategy aims at raising income rather than deleting debt. An inflationary environment would facilitate reducing the debt level. To counteract the regressive distributional effects of bank rescues, a substantial wealth tax would have to be introduced. Bailed-out financial institutions would be put under public control to ensure change in management practises. Financial regulation would lean against asset price bubbles and would use a richer set of instruments, e.g. assetspecific reserve requirement to control credit growth.

Third, there needs to be a robust mechanism of redistribution across regions that does not rely on generosity and bail-outs. A European social security system would serve that function as it redistributes income from prosperous to depressed regions without increasing debt levels. This would build a system of funding financial flows to deficit units that does not create rising liabilities for either the private or the public sector. The institutions of the labour movement have so far been opposed to transferring social policy competences to the European level: the European level has typically been more prone to pro-capital lobbying than national institutions. A European social security system would thus have to come with institution-building that guaranteed a role for labour organisations (or more broadly labour and capital) in the administration and funding decisions of the institution. 
Forth, the Keynesian policy package frees fiscal policy from the shackles of the present regime. In principle, fiscal policy has to be used to ensure that aggregate demand is at a level to ensure full employment. This implies a strong anti-cyclical component. Part of this can be delivered by automatic stabilisers like unemployment benefits and a progressive income tax, but a substantial part will be discretionary policy. States need to be able to react if their economy is facing a recession or high unemployment. Specifically, this means that the southern European countries should see large increase in government spending as their output level a well below capacity. In that situation budget deficits are desirable. Ideally these expenditures would to come out of a European budget. Effectively, these measures would amount to the creation of a European welfare state. This could give a new life to the project of European integration. And it would make economic sense.

\section{References}

Arestis, P., McCauley, C., Sawyer, M. (2001), 'An alternative stability pact for the European Union’, Cambridge Journal of Economics 25: pp. 113-130

Becker, J.; Jäger, J., (2012), 'Integration in crisis: A regulationist perspective on the interaction of European Varieties of Capitalism’, Competition and Change 16, 3, pp. 169-187

Bellofiore, R. (2005), 'The monetary aspects of the capitalist process in the Marxian system: an investigation from the point of view of the theory of the monetary circuit', In Fred Moseley (ed): Marx' Theory of Money. Modern Appraisals. (Houndsmills: Palgrave Macmillan), pp. 124-41

Bellofiore, R., Garibaldo, F., Halevi, J. (2011) 'The Global Crisis and the Crisis of European Neomercantilism', Socialist Register 2011: The Crisis This Time, (London: Merlin), pp.120-46

Bhaduri, A., Marglin, S. (1990), 'Unemployment and the real wage: the economic basis for contesting political ideologies', Cambridge Journal of Economics, 14, pp. 375-93

Bibow, J. (2007), 'How the Maastricht regime fosters divergence as well as instability’, in P. Arestis, E. Hein E. Le Heron (eds) Monetary Policies: Modern Approaches, (Houndsmills: Palgrave), pp. 197-222 
Bonefeld, W. (2002), 'European integration: the market, the political and class’, Capital and Class 77, pp. 117-

42

Brenner N., Peck J., Theodore N. (2010), 'Variegated neoliberalization: geographies, modalities, pathways', Global Networks, 10 (2), pp. 182-222

Brenner, R. (1998), ,The Economics of global turbulance‘, New Left Review 229

Credit Suisse Economics Research (2012), European Economics. Assessing debt sustainability and financing needs in Greece ahead of the PSI. https://doc.research-andanalytics.csfb.com/docView?language=ENG\&source=ulg\&format=PDF\&document_id=948097251\&s erialid=IjiUHEvdB6unRmTlYr3p6Dv6YM8Upex\%2FTeRbVrcgI6U\%3D accessed 6/9/2013

Crotty, J. (1985), 'The centrality of money, credit, and financial intermediation in Marx's crisis theory: An interpretation of Marx's methodology', in S. Resnick and R. Wolff, (eds.): Rethinking Marxism: Struggles in Marxist Theory. Essays for Harry Magdoff and Paul Sweezy. (Brooklyn, N.Y.: Autonomedia)

Crouch, C. (2009), 'Privatised Keynesianism: An unacknowledged policy regime', British Journal of Politics and International Relations 11, pp. 382-99

Dardot P, Laval C (2013), The New Way of the World: On Neoliberal Society. (London: Verso)

de Brunhoff, S , Foley, D. (2007), ‘Karl Marx’s Theory of Money and Credit. In P. Arestis and M. Sawyer (eds):A Handbook of Alternative Monetary Economics, (Cheltenham: Edward Elgar)

De Grauwe, P. (2010), The Financial Crisis and the Future of the Eurozone, Bruges European Economic Policy Briefings, 21.

Duménil, G. , Lévy, D., (1999), 'Being Keynesian in the short term and Classical in the long term: the traverse to Classical long-term equilibrium', Manchester School, 67 (6), pp. 684-716

Duménil, G., Lévy. D, (2004), Capital Resurgent. Roots of the Neoliberal Revolution. (Cambridge, MA: Harvard University Press)

Dutt, A. (2006), 'Maturity, stagnation and consumer debt: a Steindlian approach’, Metroeconomica, 57(3), pp. 339-64.

Dyson, K , Featherstone, K. (1999), The Road to Maastricht: Negotiating Economic and Monetary Union, (Oxford: Oxford University Press) 
European Commission (2012), European Economic Forecast, Spring 2012. European Economy 1/212 http://ec.europa.eu/economy_finance/publications/european_economy/2012/pdf/ee-2012-1_en.pdf accessed 6/9/2013

Foley, D., Michl, T. (1999), Growth and distribution. Cambridge, MA: Harvard University Press

Foucault, M. (2008), The Birth of Biopolitics: Lectures at the College de France, 1978-1979. (Houndsmills: Palgrave MacMillan)

Fourcade-Gourinchas, M, Babb, S (2002), 'The rebirth of the liberal creed: paths to Neoliberalism in four countries’, American Journal of Sociology 108(3), pp. 533-79

Gabor, D (2014), 'Learning from Japan: The European Central Bank and the European sovereign debt crisis’, Review of Political Economy 26(2), pp. 190-209

Glyn, A. (2006), Capitalism unleashed: Finance, Globalization and Welfare, (Oxford University Press)

Goodhart, C. (1998), 'The two concepts of money: implications for the analysis of optimal currency areas', European Journal of Political Economy, 14(3), pp. 407-432

Graeber, D. (2011), Debt. The first 5000 Years. (New York: Melville House)

Grahl, J. (2009), Global Finance and Social Europe. (Aldershot: Edward Elgar)

Grahl, J. (2012), The First European Semester: an incoherent strategy. Paper presented at the PERG workshop Europe in Crisis, April 2012, Kingston University

Hall, P. (2014), 'Varieties of Capitalism and the Euro Crisis’, West European Politics 37 (6), pp. 1223-1243

Harvey, D. (2005), A Short History of Neoliberalism, (Oxford: Oxford University Press)

Hein, E. (2012), The Macroeconomics Of Finance-Dominated Capitalism - And Its Crisis. (Cheltenham: Edward Elgar)

Hein, E. (2013), 'The crisis of finance-dominated capitalism in the euro area, deficiencies in the economic policy architecture, and deflationary stagnation policies’, Journal of Post Keynesian Economics, 36(2), $325-354$

Hein, E., Truger, A. (2005), 'European Monetary Union: nominal convergence, real divergence and slow growth? ', Structural Change and Economic Dynamics 16(1), pp. 7-33.

Huerta de Soto, J. (2012), ‘An Austrian Defense of the Euro‘. Mises Daily 22 June 2012. http://mises.org/daily/6069/ (accessed 18/11/2013) 
Huffschmid, J. (2005), Economic policy for a social Europe: a critique of neo-liberalism and proposals for alternatives, (Basingstoke: Palgrave Macmillan)

Ingham, G. (2004), The Nature of Money. Cambridge: Polity Press

Jessop, B. (2011), 'Rethinking the diversity of capitalism: varieties of capitalism, variegated capitalism, and the world market’, In Wood G, Lane C (eds), Capitalist Diversity and Diversity within Capitalism, London: Routledge, pp. 209-237

Johnston, A., Hancké, B., Pant, S. (2013), Comparative Institutional Advantage in the European Debt Crisis, LEQS Paper 66/2013

Keynes, J. M. (1973), The General Theory of Employment, Interest and Money. The collected writings of John Maynard Keynes volume VII. (Cambridge: Macmillan)

Kiefer, D., Rada, C. (2015), 'Profit maximizing goes global: the race to the bottom', Cambridge Journal of Economics 39 (5): 1333-1350

King, J. (2002), A History of Post Keynesian Economics since 1936. (Cheltenham: Edward Elgar)

Lapavitsas, C. (2000), 'Money and the analysis of capitalism: the significance of commodity money', Review of Radical Political Economics 32, pp. 631-56

Lapavitsas, C., Kaltenbrunner, A., Lindo, D., Michell, J,. Painceira, J.P., Pires, E., Powell, J., Stenfors, A., and Teles, N. (2010), 'Eurozone crisis: Beggar thyself and thy neighbour‘, Journal of Balkan and Near Eastern Studies 12 (4), pp. 321-73

Lavoie, M. (2009), Introduction to Post Keynesian economics. New York: Palgrave Macmillan

Lavoie, M., Stockhammer, E., (2013), ‘Wage-led growth: concept, theories and policies’, in M. Lavoie, and E. Stockhammer (eds): Wage-led growth. An Equitable Strategy for Economic Recovery, (London: Palgrave Macmillan), pp. 13-39

Lucarelli, B. (2011), 'German neomercantilism and the European sovereign debt crisis‘, Journal of Post Keynesian Economics 34, 2: 205-24

Marx, K. (1976), Capital. A Critique of Political Economy Volume One. (London: Penguin Books)

Mehrling, P. (2011), The New Lombard Street, How the Fed Became the Dealer of Last Resort. (Princeton, NJ: Princeton University Press) 
Minsky, H. (1986), Stabilizing an unstable economy. (New Haven: Yale University Press)

Mirowksi, P., Plehwe, D. (2009), The Road from Mont Pelerin. (Cambridge, MA: Harvard University Press)

Nölke, A. (2014), 'Economic causes of the Eurozone crisis. The analytical contributions of Comparative Capitalism’, Manuscript

Onaran, Ö., Galanis, G., (2014), 'Income distribution and growth: a global model', Environment and Planning A 46 (10), pp. 2489-2513

Pisani-Ferry, J., Wolff, G. (2012), Is LTRO QE in disguise? http://www.voxeu.org/index.php?q=node/7923 (accessed 20/11/2013)

Ryner, M. (2015), ‘Europe's ordoliberal iron cage: critical political economy, the euro area crisis and its management', Journal of European Public Policy, 22 (2), pp. 275-294

Schulten, T., Watt, A. (2007), European minimum wage policy -a concrete project for a social Europe. ETUI European Economic and Employment Policy Brief No 2-

Stockhammer, E., Onaran, Ö. and Ederer, S. (2009), 'Functional income distribution and aggregate demand in the Euro area', Cambridge Journal of Economics, 33 (1), pp. 139-159

Stockhammer, E., Sotiropoulos, D. (2014), 'Rebalancing the Euro area: the costs of internal devaluation', Review of Political Economy 26, 2, pp. 210-33

Stockhammer, E., Wildauer, R., (2016), 'Debt-driven growth? Wealth, distribution and demand in OECD countries', Cambridge Journal of Economics forthcoming

Stockhammer, E. (2008), ‘Some Stylized Facts on the Finance-Dominated Accumulation Regime’, Competition and Change 12, 2, pp. 189-207

Stockhammer, E. (2011), ‘Peripheral Europe’s debt and German wages’, International Journal for Public Policy 7 (1-3), pp. 83-96

Stockhammer, E. (2012), ‘Financialization, income distribution and the crisis’, Investigación Económica, 71 (279), pp. 39-70

Stockhammer, E. (2016), 'Determinants of the wage share. A panel analysis of advanced and developing economies‘. British Journal of Industrial Relations forthcoming

Walby, S. (2013). 'Finance versus democracy? Theorizing finance in society’, Work, Employment \& Society 27 (3), pp. 489-507 
Weeks, J. (2014) 'Euro crises and euro scams: Trade not debt and deficits tell the tale’, Review of Political Economy 26 (2), pp. 171-89 
Table 1. A typology of distribution and growth regimes

\begin{tabular}{|c|c|c|c|}
\hline & & \multicolumn{2}{|c|}{ Actual distributional changes } \\
\hline & & Pro-capital & Pro-labour \\
\hline \multirow[t]{2}{*}{ Demand regime } & Profit-led & $\begin{array}{l}\text { Virtuous profit-led } \\
\text { growth process } \\
\text { ('neoliberalism in } \\
\text { theory) }\end{array}$ & $\begin{array}{l}\text { Stagnation or } \\
\text { external demand } \\
\text { stimulation ('Failed } \\
\text { social reform') }\end{array}$ \\
\hline & Wage-led & $\begin{array}{l}\text { Stagnation or } \\
\text { external demand } \\
\text { stimulation, e.g. via } \\
\text { debt-driven or } \\
\text { export-driven growth } \\
\text { ('actually existing } \\
\text { neoliberalism’) }\end{array}$ & $\begin{array}{l}\text { Virtuous wage-led } \\
\text { growth process } \\
\text { ('social } \\
\text { Keynesianism') }\end{array}$ \\
\hline
\end{tabular}

Source: adapted from Lavoie and Stockhammer 2013 
Table 2. Increase in household debt (in \% GDP), 2000-08

\begin{tabular}{|l|c|l|c|}
\hline \multicolumn{2}{|l|}{ Northern European Countries } & \multicolumn{2}{l|}{ Anglo-Saxon Countries } \\
\hline Germany & -11.3 & USA & 26 \\
\hline Netherlands & 32.8 & United Kingdom & 28.1 \\
\hline Austria & 7.9 & Southern European Countries \\
\hline France & 15.8 & Ireland & 62.7 \\
\hline & & Greece & 35.5 \\
\hline & & Spain & 27.4 \\
\hline & & Portugal & \\
\hline Source: Eurostat, except USA: FoF & & \\
& & & \\
\hline
\end{tabular}


Table 3. Increase in unit labour costs (ULC), 2000-08

\begin{tabular}{|l|c|l|c|}
\hline \multicolumn{2}{|l|}{ Northern European Countries } & \multicolumn{2}{l|}{ Southern European Countries } \\
\hline Germany & $3 \%$ & Ireland & $33 \%$ \\
\hline Netherlands & $19 \%$ & Greece & $26 \%$ \\
\hline Austria & $9 \%$ & Spain & $30 \%$ \\
\hline & & Italy & $27 \%$ \\
\hline Euro Area (12) & $16 \%$ & Portugal & $24 \%$ \\
\hline
\end{tabular}

Source: AMECO 